This is the accepted manuscript submitted to Edinburgh University Press which will appear in issue 22(2) of the Edinburgh Law Review

\title{
Abandonment of land and the Scottish Coal case: was it unprecedented?
}

\section{A. INTRODUCTION}

Owners of land do not usually wish to abandon it. Land is scarce and is normally a valuable commodity. It seems strange that there might be circumstances where someone would seek to relinquish a slice of Scotland in exchange for no benefit. Notwithstanding, the liquidators of a landowner recently tried to do this in relation to certain sites that had been used for coal mining. In the Scottish Coal case, ${ }^{1}$ those liquidators petitioned the Court of Session for guidance as to whether it was possible to abandon land and, if so, the proper procedure for doing so. It was ultimately held that it was not competent to abandon land in Scots law. As we shall see, the case prompted some useful contemporary commentary, which this note will develop. It will also seek to analyse one specific and as yet unaddressed point raised in the course of proceedings. Both the Outer and Inner Houses recognised that there was a distinct lack of authority as regards the abandonment of land. As Lord Hodge stated, "Counsel were not able to find any authority which supported the idea that an owner could abandon land in Scotland". ${ }^{2}$ Likewise, the Inner House observed the "simple fact" that "noone in the court was aware of any instance in which a person (corporate or otherwise) had 'abandoned' or 'disclaimed' heritable property, so as to render it ownerless."3 This may seem surprising in a system as developed as Scots law. After outlining the matters raised in the case, this note will consider why the legal point had not arisen prior to the particular circumstances of Scottish Coal, and highlight some issues for further consideration.

\section{B. FACTS OF THE CASE}

The Scottish Coal Company Limited owned sites used for open-cast mining in Ayrshire, Lanarkshire and Fife. When the court ordered the winding up of the company, the petitioners were appointed as joint liquidators. Several sites or part-sites remained unsold. The cost of future compliance with environmental regulation with regard to these sites was estimated to

\footnotetext{
${ }^{1}$ The Scottish Environment Protection Agency and Others $v$ The Joint Liquidators of the Scottish Coal Company Ltd [2013] CSIH 108 ("Scottish Coal CSIH”); Joint Liquidators of the Scottish Coal Co Ltd, Noters [2013] CSOH 124 (hereafter "Scottish Coal CSOH").

${ }^{2}$ Scottish Coal CSOH, para 22.

${ }^{3}$ Scottish Coal CSIH, para 97.
} 
be around $£ 478,000$ per month. ${ }^{4}$ Such costs would swallow up the assets of the Scottish Coal Company. In order to protect unsecured creditors and the holders of a floating charge, the liquidators sought direction from the court on several questions.

The question of central importance in this note was whether the liquidators could disclaim (abandon) ownership of the land. ${ }^{5}$ If this was possible then the liquidators, released from the environmental costs, would have some assets left to distribute to the creditors. Due to the environmental damage and the ensuing costs (which would still have to be met by someone) for any restoration or indeed to ensure the aversion or mitigation of any further damage, various public bodies opposed the liquidators. ${ }^{6}$ In the Outer House Lord Hodge concluded that the liquidators could disclaim ownership of the sites. The Inner House (Lord Carloway, along with Lords Brodie and Menzies) disagreed, holding that the heritable property could not be abandoned.

\section{TREATMENT OF ABANDONMENT OF LAND IN THE CASE}

Abandonment was considered in the strict sense of casting away the real right of ownership, not merely physically leaving or ceasing to use the land. ${ }^{7}$ Abandonment in this legal sense seeks to end ownership by the unilateral action of the current owner with no third party involvement. $^{8}$

The novel character of the Scottish Coal case meant it attracted some attention. ${ }^{9}$ In the absence of specific Scots authority on the abandonment of land, Lord Hodge (relying on the

\footnotetext{
${ }^{4}$ The relevant environmental regulatory provisions were: the Water Environment (Controlled Activities) (Scotland) Regulations 2005, SSI 2005/348, and 2011, SSI 2011/209; and the Pollution Prevention and Control (Scotland) Regulations 2000, SSI/323.

${ }^{5}$ For discussion of the insolvency related aspects of the case, see C Ingle, "Heritage regained" (2014) 59(3) Journal of the Law Society of Scotland 32.

${ }^{6}$ These were the Scottish Environment Protection Agency, Scottish Natural Heritage, East Ayrshire and South Lanarkshire Councils, and the Lord Advocate on behalf of the Scottish Ministers.

${ }^{7}$ K Swinton, "Dealing with abandoned property" 2015 83(4) Scottish Law Gazette 64-65 highlights this distinction. The usage of the word "abandoned" in Part 3A of the Land Reform (Scotland) Act 2003, which gives a community the right to acquire land that is "wholly or mainly neglected or abandoned", poses some separate questions, but it seems clear that the word "abandoned" in that statute must have a meaning other than the technical property law sense, not least because the scheme of the right to acquire is predicated on acquiring from someone. This particular community right to buy is not yet in force.

${ }^{8}$ For non-Scots law commentary on this strict legal sense of abandonment, see further: E Peñalver, "The illusory right to abandon" (2010) 109 MichLR 191; L J Strahilevitz, "The right to abandon” (2010) 158 U. Pa. L. Rev. 355; R Hickey, "The problem of divesting abandonment" (2016) 80(1) The Conveyancer and Property Lawyer 28; and R Cramer, "The abandonment of landownership in South African and Swiss law" (2017) 134 SALJ 870. See also D W Elliot "Land without an owner" (1954) 70 LQR 25.

${ }^{9}$ K Swinton, "The ability to abandon title to land: SEPA v Scottish Coal” 2014 Scottish Law Gazette 16; C Ingle (n5); Swinton (n7); K G C Reid and G L Gretton, Conveyancing 2013 (2014) 196-199. Academic coverage of land abandonment prior to this case was largely restricted to textbooks, most notably W M Gordon and S Wortley, Scottish Land Law (SULI, 3rd edn) Vol 1 (2009) paras 13-19 - 13-22.
} 
logic of Roman-Dutch law ${ }^{10}$ and German law $^{11}$ ) concluded that abandonment of land was possible in Scots law, being an essentially Civilian system of ownership. He also drew an analogy with corporeal moveable property, but noted that the procedure would need to be regulated by the court to prevent any abuse by a landowner. ${ }^{12}$ The decision was overturned on appeal. The Inner House clarified that the only ways ownership might end are actual destruction (say by coastal erosion), dissolution of a company, the law operating to divest someone of land (through diligence) or voluntary transfer. Abandonment of land in a strict sense is not possible. ${ }^{13}$ "There is no legal process whereby a person can transfer land into oblivion." 14

The Inner House did however agree with Lord Hodge that it seemed that the Scottish Coal case was the first to address abandonment of land in Scots law. The authors of this note have also been unable to find any prior authority. This dearth of relevant case authority may be explained by several factors.

\section{LACK OF PRECEDENT ON ABANDONMENT OF OWNERSHIP OF LAND}

\section{The feudal system}

The feudal system of land tenure was ended on 28 November 2004 by the Abolition of Feudal Tenure etc. (Scotland) Act 2000. ${ }^{15}$ Holders of the dominium utile in the land - being at the lowest level of the feudal hierarchy, but with practical control of the land - became owners under a regime of simple ownership, removing the crown from its apex role as dominium eminens. ${ }^{16}$ The comparatively recent abolition of feudalism may explain the lack of cases prior to 2013, for the following reasons.

\section{(a) Abandonment in a feudal system did not create a vacuum}

\footnotetext{
${ }^{10}$ The major South African authority is contained in the case of Minister van Landbou v Sonnendecker 1979 (2) SA 944, and see now Cramer (n8). why this should not be the case. If it is possible to abandon corporeal moveable property, it should be possible to abandon land. But in the absence of a statutory regime, it seems to me that the court should regulate such abandonment to prevent its abuse as a means of avoiding obligations." Scottish Coal CSOH, para 26. That procedure was found in paras 72-76.

${ }^{13}$ Scottish Coal CSIH, paras 101-102.

${ }^{14}$ Scottish Coal CSIH, para 103 per Lord Carloway.

${ }^{15}$ Abolition of Feudal Tenure etc (Scotland) Act 2000, section 1. See further K G C Reid, The Abolition of Feudal Tenure in Scotland (2003).

${ }^{16}$ On this, see Craig Ius Feudale 461, 16, 7.
} 
If the dominium utile was abandoned the title would revert up the feudal chain. The law developed so that where the abandonment was public the Crown took priority over the immediate feudal superior (the dominium directum) and received the dominium utile. ${ }^{17}$ Meanwhile, consolidation allowed the holder of the dominium directum to acquire the dominium utile through resignation ad remanentiam $^{18}$ or via prescription, depending on the factual situation. Positive prescription allows possessors of land to obtain title to it in certain circumstances, including the passage of a defined time period in possession (40 years in terms of the Prescription Act 1617 and now ten years by the Prescription and Limitation (Scotland) Act 1973). Cases of consolidation indicate the importance of prescription where the right to the dominium utile was not exercised. ${ }^{19}$ Failure to use the dominium utile is analogous to the effect of abandonment.

\section{(b) Abandonment of land was conceptually challenging}

The fragmented form of landownership under feudalism was fundamentally different to the current allodial system. ${ }^{20}$ No single party was proprietor of all the rights of ownership in the current sense. Whilst abandonment of moveables was not conceptually impossible, ${ }^{21}$ abandonment of landownership could not have been conceived in the current sense. The feudal ownership of land in a layered system meant that it was considered in a manner distinct from the ownership of moveables. Accordingly, the logic of abandonment of moveables could not be applied to the ownership of land under a feudal system. ${ }^{22}$ The nearest

\footnotetext{
${ }^{17}$ A R G M'Millan, Law of Bona Vacantia in Scotland (1936) 5, discussed in Scottish Coal CSIH at para 107. The feudal superior may have had a claim in some circumstance though: where non-use was accompanied by non-payment of feu duty, a question of forfeiture might arise: see Gordon and Wortley (n9) para 13-19. For completeness, in a situation of multiple superiorities it can be surmised that abandonment by a mid-feudal superior would have led to a similar priority for the Crown over any other superiors. It can also be observed that complete abandonment by the office of the Crown would be incompatible with feudalism. Both those situations are beyond the scope of this note.

${ }^{18}$ Hay v Paterson 1910 SC 509 at 515 per Lord President Dunedin; Walker v Grieve 18275 S. 469. See also K G C Reid, The Law of Property in Scotland para 97 (written by G L Gretton) and G J Bell, Principles of the Law of Scotland, 4th edn (1839; reprinted as Old Studies in Scots Law, vol. 1, 2010) 786-805.

${ }_{19}$ Wilson v Pollok 18392 D. 159; Bruce v Carstairs 1770 Mor. 10805; Bald v Buchanan 1786 Mor. 15084.

${ }^{20}$ TB Smith, Short Commentary on the Law of Scotland (1962) 460.

${ }^{21}$ As M'Millan put it, when rejecting a reversionary theory of bona vacantia, "moveables are held not in tenure but in full ownership": Bona Vacantia in Scotland (n 16) 3. See also D L Carey Miller with D Irvine Corporeal Moveables in Scots Law 2nd edn (2005) para 2.02 and Lord Advocate v University of Aberdeen 1963 SC 533.

${ }^{22}$ The Crown right to res nullius under the principle quod nullius est fit domini regis was not a feudal one. In Scottish Coal CSIH, it was submitted by counsel for one of the successful parties (para 48) that the Crown right to unowned things "was part of the prerogative right (jus coronae) to the territory of Scotland": para 47, with reference to Lord Ross in Shetland Salmon Farmers Association v Crown Estate Commissioners, 173.
} 
unilateral action may have been resignation ad remanentiam. Feudal tenure could be seen as obscuring the Roman rules which might otherwise have operated. ${ }^{23}$

\section{Negative value land}

The land in Scottish Coal had become a negative value asset due to the costs of compliance with environmental regulation. Such negative value plots of land would have been historically anomalous. ${ }^{24}$ This means positive prescription has a further relevance to this analysis: prescription would have been more likely to occur where land was of positive value and thus desirable, again reducing any scope for outright abandonment. Returning to the present day, Lord Hodge observed this in Scottish Coal;

At a time when the ownership of land has been become regulated in the public interest through planning and environmental legislation, it is easy to see why a unilateral power to abandon land could be abused if it existed..$^{25}$

With the increased potential for negative value land, it follows that there will be greater motivation to abandon land. ${ }^{26}$ For this reason scenarios such as Scottish Coal are now more likely to arise than would have been the case historically. It is more difficult to envisage types of land that would have constituted near permanent negative value assets prior to industrialisation or any other excesses of the Anthropocene. This, it is submitted, is part of the reason for the lack of cases on the issue.

\section{E. CONCLUSION}

The historic feudal law and the historical rarity of negative value land, which could combine with the doctrine of positive prescription, offer a plausible explanation for the absence of Scots law jurisprudence on abandonment. That backdrop might contribute to the unease which modern Scots law (as reflected in the Inner House decision) has with land abandonment. In the first edition of their textbook, written after feudal abolition but preScottish Coal, Gretton and Steven stated that: "Ownership of land is now like the ownership of moveables: ownership in the Roman sense." ${ }^{27}$ If this was the case then it might be

\footnotetext{
${ }^{23}$ M'Millan, Bona Vacantia (n17) 7.

${ }^{24}$ This is not to say negative value assets are unique to our era: see R van den Bergh, 'Ownership of agri deserti during the later Roman Empire’, (2004) 67 Tydskrif vir Hedendaagse Romeins-Hollandse Reg 60, where the abandonment of agricultural land to avoid high taxes is discussed. Other reasons mentioned by van der Bergh include barbarian hordes, exhaustion of soil and shortage of agricultural labour.

${ }^{25}$ Scottish Coal CSOH 124, para 22.

${ }^{26}$ Strahilevitz (n8), 363.

${ }^{27}$ G L Gretton and A J M Steven, Property, Trusts and Succession, (2008) 463. This was retained in the second edition (485) and in the third edition (504) notwithstanding the Scottish Coal case.
} 
presumed that abandonment of land would follow the same rules as abandonment of moveables. Gordon and Wortley also presumed this position (also prior to Scottish Coal case). ${ }^{28}$ This was not the result in Scottish Coal. ${ }^{29}$ It now transpires that the abolition of feudal tenure in Scotland has not given carte blanche for the abandonment of land. What of the future? With increasing public regulation of land, there will be conditions in which abandonment will seem the least-worst option, as it was for the liquidators in Scottish Coal. In certain circumstances the burden of continued ownership may be almost penal (particularly where an owner has been caught by changing circumstances and has not contributed to a negative value situation). The question will then arise as to whether the current rule is fair. (There is a separate question of whether the rule leads to efficient allocation of resources across society.) There may be follow-on questions about what steps might be taken to mitigate a blanket prohibition of abandonment, perhaps by offering a mechanism to ease transfer to another party (assuming a willing transferee can be found) or offering a means for another party to acquire ownership other than the existing rules of positive prescription. Abandonment of heritable property raises many yet to be determined conceptual and practical points. The relatively recent abolition of feudalism coupled with emerging public regulation of land and indeed Scotland's wider land reform agenda provide an ideal opportunity to consider how to address land abandonment in a way that is suitable for modern Scotland. Further comment should be anticipated and could yet form the basis of another note.

Malcolm M Combe, University of Aberdeen

Malcolm I Rudd, Trainee Solicitor

The support of the Carnegie Trust for the Universities of Scotland in the provision of a research incentive grant that contributed to this note is gratefully acknowledged.

\footnotetext{
${ }^{28}$ Gordon \& Wortley, Scottish Land Law (n9) para 13.20.

${ }^{29}$ In a passing and suitably caveated comment on whether landownership can be abandoned, Professors Reid and Gretton stressed they offered no view on the "difficult" issues involved, but took the opportunity to observe "in general in private law rights may be given up, so that if ownership of land cannot be abandoned, the result is asymmetrical": Conveyancing 2013 (n9) 197.
} 